\title{
Employment Oriented English Talents Training Under the Background of "the Belt and Road Initiatives"
}

\author{
Zhang Lu \\ Shaanxi Polytechnic Institute \\ Xianyang Shaanxi 712000
}

\begin{abstract}
As a national strategy, "the Belt and Road Initiatives" is experiencing the continual development and improvement, and more and more English major talents are required to guarantee the smooth implementation and construction of the strategy. With regard to the situation, those colleges and universities have greatly changed their training model aiming at English major talents. Regarding the training of English talents as the emphasis, this paper discussed the practical training schemes and plans for employment-oriented English talents with the basis of the relevant study on "the Belt and Road Initiatives" strategy construction, aiming at highlighting the focus, objective and teaching style innovation of employmentoriented teaching methods to English talents training. There are some obvious disadvantages of the current employment-oriented English talents training reflecting on the education objectives, for instance, the incoherence, imperfect education system, lackingpertinence education method, as well as not being able to accurately meet the practical demand of English talents under the employment environment. Therefore, there is no doubt that it is necessary to make a discussion with the application-oriented English major talents.
\end{abstract}

Keywords-"the Belt and Road Initiatives"; employmentoriented ; English talents

\section{INTRODUCTION}

President Xi Jinping successively put forward the strategy conception respectively named "the Silk Road Economic Belt" and "the 21st Century Maritime Silk Road" when revisiting Central Asia and ASEAN (the Association of Southeast Asian Nations) in September, 2013, which endows the ancient silk road with new vitality and connotation to provide a new opportunity for Asian and pan-Asian economic cooperation and regional development. The third plenary session of the 18th central committee of the CPC explicitly mentioned that the construction of "the Silk Road Economic Belt" and "the Maritime Silk Road" are supposed to be advanced so that the new all-rounded and opening-up pattern can be formed. In the meanwhile, the related financial support mechanism made the arrangement, for example, the architecture with three pillars of the financial support institutions, the Silk Road Fund, the Asian Infrastructure Investment Bank and the original BRICKS Bank, which offered its powerful support for "the Belt and Road Initiatives". However, English talents are desperately needed to be the resource and impetus for the development of "the Belt and Road Initiatives", the process of China walking to the global economy and trade and political arena, so it requires that Chinese college English education should realize the transformation of major-oriented to employment-oriented, and various of English talents training model are certainly generated.

\section{THE BACKGROUND AND CONNOTATION OF “THE BELT AND ROAD INITIATIVES"}

\section{A. The background of "the Belt and Road Initiatives"}

There was a profound historical background to propose "the Belt and Road Initiatives". The economic development and reform of contemporary China are in the "sham" period where the opening-up policy is facing the adjustment and transformation and economic development is at a slower pace and weaker degree. And the new stage, mixed with the transformation, growing pains and digestion, is decided by the objective laws of domestic economic development. Ever since the 21 st century, domestic economy has witnessed a rapid development but redundant structures, so the abrupt economic situation reform has brought a new challenge with the longstanding economic development model and solved the urgent issue existing in our country for many years under the new economic situations that the deep-layer contradict of economic development. And as RMB joined SDR, the gradually aggravating integrated pattern of international economy, more complex construction development situation of regional economy and increasing global economy have raised new demands with Chinese economy. Thus, our country is under the both pressures of internal and external economic development at present. And "the Belt and Road Initiatives" is founded under such economy background that Chinese economic development is urgently need to establish the interconnected economy and trade relation with neighboring economies so as to expand the regional impact and deepen the influence in the field of international economy. In addition, the status of China has been further deepening in the Far East economic development and global economy and trade along with the establishment of "the Belt and Road Initiatives".

\section{B. The connotation of "the Belt and Road Initiatives"}

"The Belt and Road Initiatives" is mistaken as Chinese west advancement strategy to some extent, including the international and domestic respects ( Jianmin Li, 2013). In fact, 
this strategy is the significant platform of Chinese opening-up to the western. The construction conception of "the Silk Road Economic Belt" and "the Maritime Silk Road" was firstly proposed by General Secretary Xi Jinping during the visit to four Central Asian states and Indonesia in September and October of 2013. Subsequently, the specific framework and conception of "the Belt and Road Initiatives" have been further deepen, and as a comprehensive and strategic conception, its strategic connotations are: accelerating the regional cooperation and connection, opening Chinese strategic cooperation of other Asian countries, forming a Community of Common Destiny and continually deepening the mutual help and cooperation with Western developed countries; while its cultural connotations are: prospering the ancient silk road, inheriting the historical spirits, inspiring the cultural development construction of new era and offering certain thought and reference; and its economic connotations are: promoting Chinese economic relation and trade communication with economies along the road, developing regional economy as well as deepening the status of Chinese export trade in the international market.

\section{THE EXISTING PROBLEMS IN THE CURRENT ENGLISH MAJOR TALENTS TRAINING}

Affected by the traditional English talents training model, even though current English talents have paid attention to the simultaneous teaching of fundamental knowledge and skills in the training process, there still exist some problems in the aspect of comprehensive application. These problems are interconnected with the level of modern education system and social economic development and possess some historical characteristics. While along with the overall implementation of "the Belt and Road Initiatives", the requirement number and ability demand of English major talents are supposed to constantly improved, which also result in some problems existing in the current English major talents training. The specific manifestations are as follows:

\section{A. Imperfect employment-oriented teaching system}

It is the vital factor for the problem in the whole teaching and related imperfect teaching practical function that Chinese college English education lacks the theory of employmentoriented teaching system which is essential to the instruction of teaching practice. A set of teaching theory with high maturity and perfect system can be better served for the corresponding teaching work; otherwise, it will be the primary reason for practical teaching process ignoring students' personal development and vocational ability development part preferring to lacking systematic teaching rules. As a result, the new situation of economic development desperately requiring English talents cannot easily adapted and it will be relatively hard for English talents to adapt to the English practical skills frequently used in the position so that the talents development will be limited. Secondary, employment-oriented teaching system lacks a management scheme with a unified standard. The time conflict of prevailing English teaching system with the corresponding employment-oriented teaching reform makes lots of schools have no unified teaching regulation to make the reference. What's more, faced with several of English majors, the current managing system usually lack the efficiency and flexibility, which will result in the bigger problems in the corresponding teaching part.

Imperfect system will also cause the problem such as the mismatching of teaching and employment, relatively low adaptability and efficiency of students in society and working post and genuine not able to applied to the practical work, all of which will create a situation of high learning and low competence.

\section{B. The class teaching atmosphere with distinct teaching emphasis has not been created yet}

The application of multimedia facilities and digital systems in the modern English education has made teaching more convenient and efficient, but its large-scale application also has caused some problems. It is generally known to us that the application of multimedia system realized students' well adaptability in the learning environment, familiar with the basic sentence patterns and understanding with the function of the basic sentence elements. For instance, teachers select the famous aphorisms with good grammar and sentence structure randomly expressed in the multimedia system to deepen the further understanding of students to the sentence structure and grammar, for example, All is not gold that glitters; He who does not reach the Great Wall is not a great man. In the meantime, the translation practice between English and Chinese can be more intensively made and knowledge mastering can be better achieved through the analysis and translation with common sentences, both of which also reduce the teaching burdens of teachers. Multimedia teaching courseware is of great characteristics with well recycling, addition and deletion, enhancing the saving degree of teaching resources to a great extent, while such teaching environment ignores the direct knowledge imparting, and many students attend trifles and neglect essentials. And it seems that the teaching efficiency has been strengthened, but the condition of practically knowledge mastering is greatly reduced and there still exists some problems in the process of realizing the distinct primary and secondary teaching emphasis.

\section{PRINCIPLES OF EMPLOYMENT-ORIENTED ENGLISH TALENTS TRAINING}

The education and training of employment-oriented English talents is a significant measure and comprehensive reform of education methods corresponding with Chinese economy and social development. It overthrew the irrational education pattern in the traditional English teaching that attaches knowledge and skill but disconnected with social actual demands, while regarding the talent training meeting social demands as its premise. So, there have been various majors such as business English and accounting English in the modern higher English teaching, and these new majors combined with English and based on society represent the reform direction of future English teaching, also being the implementation platform of employment-oriented English teaching. While the employment-oriented English talents training have the several following principles: 


\section{A. The principle of interest}

"Interest" is the best teacher, so education also is supposed to focus on students' actual learning interest, while the former traditional English pattern are paying more attention to the target of English teaching but ignoring the subject of teaching education - students. As a result, lots of students feel very hard when learning English and generate the psychological repellence. But the primary principle of employment-oriented English teaching is interest and the teaching process is made on the basis of students' interest in order to make them directly adapt to their future employment. In addition, this teaching pattern is able to maximally guarantee the optimum degree of students on their professional ability and expected value of occupation. What's more, students will be more responsible and equipped with the corresponding occupational attitude when working in the English field under the new teaching pattern; for it is based on their interest and they will discard many confused and diffident parts.

\section{B. The principle of practice}

English education, requiring the combination of practical exercise and theoretical knowledge, is the essential content of talents training faced with "the Belt and Road Initiatives" development strategy. And its practical principle is not same with the former teaching method with pure skill teaching and experiment exercise, but attaching more importance to students' ability training of extracurricular practice and expanding practice and awareness training. In addition, it highlights the atmosphere of communication with English and mutual learning, making domestic "dumb" English acquires the actual practice opportunity and provides corresponding motivation for the occupational ability development of students. Given the problem that current college English education lacks the practice opportunity and actual education degree deviates from the requirement of teaching standard, employmentoriented teaching concept can better achieve its entire progress. It can be seen that practice principle is the significant component of employment-oriented English talents teaching and key point to the training of creation ability. In the process of innovation ability training, it should be constantly based on the demand of actual development to achieve the study on innovation teaching concept and methods as well as serve the training of English teaching to the talent creation ability.

\section{EMPLOYMENT-ORIENTED ENGLISH TALENTS TRAINING UNDER THE BACKGROUND OF “THE BELT AND ROAD INITIATIVES"}

\section{A. Training objectives}

As for the current colleges and universities, it is especially vital that establishing the training objective of employmentoriented English talents which a good indicator to English talents is training. It means that English talents will have greater access to joining Chinese trade with foreign countries and making their contribution to these international business and trade cooperation as the pioneer, which will help the foreign circulation of domestic products, positively absorb the foreign investment on domestic industries and achieve the optimal allocation of resources. That is the reason why the college English major talents training under the "the Belt and Road Initiatives" are supposed to be equipped with well English ability, including listening, speaking, reading, writing, translating and corresponding social ability, such as thinking logic, regional culture, business and trade rules, global situation and state development strategy, etc. In the same vein, they should have such inner cultivation and quality, like the nice ability of communication and anti-pressure and spirit of devotion and fighting. All of these require modern English talents to possess well comprehensive ability and be able to adjust their own countermeasures according to the change of situation and corresponding requirements.

\section{B. Training methods}

Reform the education and teaching system. In order to comprehensively and deeply reform the education system, the first step is to reform the teacher-centered pattern, namely, it is mainly with teachers' teaching and students' passive learning. Return the initiative of class to students, while teachers can enlighten students' thought through teaching cases and focus on making students get to know what the emphasis is and get hang of them based on the prospect of employment, but avoiding the teaching method of "spoon-feeding" in the traditional teaching system. In the meantime, the work of test and check should be strengthened. Teachers should simulate aiming at the actual employment requirements to assess the practical ability of students.

Arrange the courses scientifically and rationally. The courses arrangement should be based on the curricular system of "English + major + second foreign language". "English" means the course of English skill and major basis; while "major" means the course of occupation post ability closed with the market demand under "the Belt and Road Initiatives"; and "second foreign language" means the minority language. The proportion of these three parts should be rationally arranged in the process of courses arrangement, and the setting the courses categories should be according to the current institution. In addition, colleges are supposed to focus on shaping the practical ability of students and open the practice course via the organic combination with theories of professional courses.

Strengthen the training of English professional teachers and reforming of teaching concepts. Teachers play a significant role in promoting the employment-oriented English teaching, which requires teacher to enhance their daily teaching studying make deep learning with the professional requirement and innovative teaching methods of employment-oriented English teaching, for instance, making the daily teaching with a practical teaching system with the multimedia teaching and mixed teaching methods, improving the guidance with students during teaching and guiding them to promote their awareness and make deep learning with employment-oriented English teaching pattern basically.

\section{CONCLUSIONS:}

In conclusion, this paper analyzed the problems existing in the English major talents training under the background of "the Belt and Road Initiatives", combined the opportunity and 
challenge that English talents are faced with and finally put forward the measure to strengthen the employment-oriented English talents training, for example, emphasizing the reform of education and teaching system, rational arrangement of courses and enhancing the occupational quality of teachers, all of which can provide the researchers with reference. The innovative point of this paper was that it combined the real English talents training model and future demand, and achieved a new viewpoint of the employment-oriented English talents training under the background of "the Belt and Road Initiatives" in the comparing process.

\section{REFERENCES}

[1] Tingting Wang. The Primary Discussion with the Employment-oriented English Talents Training under the Background of "the Belt and Road Initiatives" [J]. Journal of Language and Literature Studies (Foreign language education and teaching), 2016,(06):105-108+124.

[2] Xiaocong Duan. A Study on the Business English Talents Training of Higher Vocational Colleges under the Background of "the Belt and Road Initiatives"- Take vocational colleges in Guangdong province as an example [J]. Western Quality Education, 2015,1(07):53+55.

[3] Ting Xie. The Compound English Talents Training of Business English under the Background of "the Belt and Road Initiatives" [J/OL]. Technology Outlook, 2017,(23):196-197.

[4] Guojian Zhang. A Study on the Language Skill Training of Cross-border E-commerce English Talents under the Background of "the Belt and Road Initiatives" - Take Xi'an as an example [J]. Economic Research Guide, 2017,(09):133-135.

[5] Xiaofei Liu. The Employment-oriented English Talents Learning under the Background of "the Belt and Road Initiatives" [J]. Intelligence, 2016,(28):185. 